\title{
Acute hippocampal and chronic diffuse white matter involvement in severe methanol intoxication
}

Figure $1 \quad$ MRI on admission
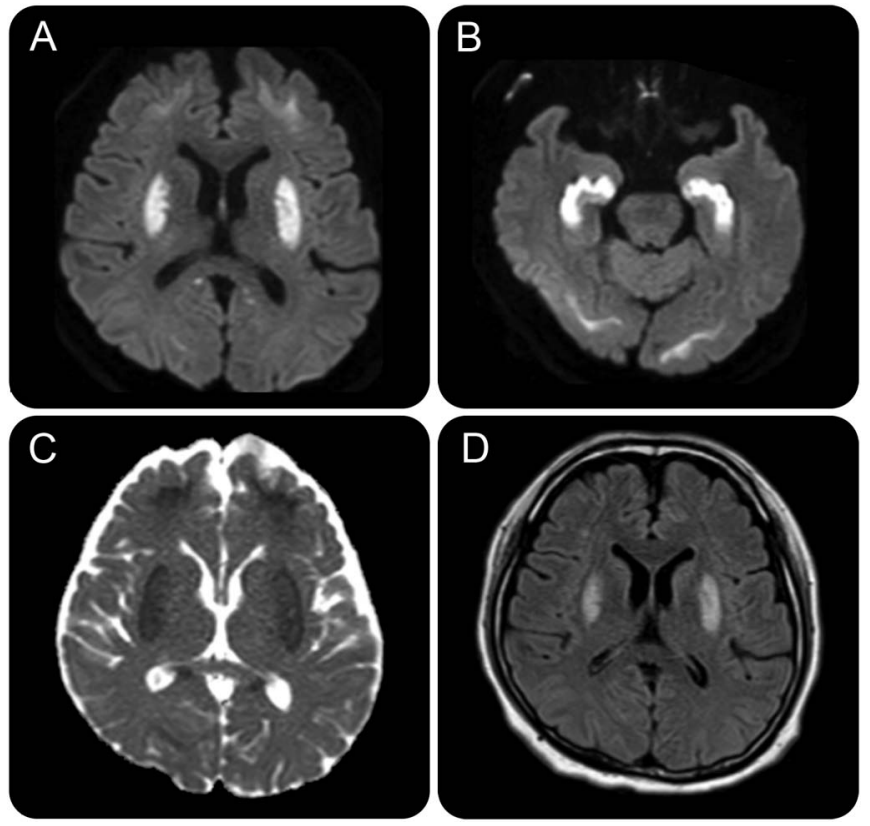

Representative images of brain MRI on admission, including diffusion-weighted imaging (A, B), the apparent diffusion coefficient map (C), and fluid-attenuated inversion recovery image (D), show hyperintense lesions in the bilateral putamen, hippocampi, and subcortical white matter.

A 42-year-old man presented with coma from methanol intoxication $(178 \mathrm{mg} / \mathrm{dL}$; its metabolite, formic acid, $860 \mu \mathrm{g} / \mathrm{mL}$ ). Continuous hemodiafiltration improved his disturbance of consciousness, but he subsequently developed cognitive dysfunction and parkinsonism, which were finally alleviated by rehabilitation and amantadine therapy. Brain MRI revealed acute basal ganglionic and hippocampal lesions and chronic developmental white matter lesions (figures 1 and 2).

Formic acid disrupts mitochondria, resulting in cytotoxic hypoxia and oxygen free radical production, which might cause acute putaminal and hippocampal injuries. ${ }^{1}$ Oxygen free radicals contribute to the development of white matter lesions. ${ }^{2}$ In our case, toxic encephalopathy likely resulted from diverse mechanisms.

Haruka Takeshige, MD, Yuji Ueno, MD, PhD, Fuyuko Sasaki, MD, Akira Namera, PhD, Takehisa Matsukawa, PhD, Kazuhito Yokoyama, MD, DMSc, Nobutaka Hattori, MD, PhD

From the Juntendo University Faculty of Medicine (H.T., Y.U., F.S., T.M., K.Y., N.H.), Tokyo; and Institute of Biomedical and Health Sciences (A.N.), Hiroshima University, Japan.

Author contributions: Dr. Takeshige: drafting the manuscript, acquisition of data. Dr. Ueno: drafting the manuscript, study conception, interpretation of data, acquisition of data. Dr. Sasaki: interpretation of data, acquisition of data. Dr. Namera: interpretation of data, acquisition of data. Dr. Matsukawa: interpretation of data, acquisition of data. Dr. Yokoyama: interpretation of data, acquisition of data. Dr. Hattori: critical revision of the manuscript for important intellectual content, study supervision.

Study funding: No targeted funding reported.

Disclosure: The authors report no disclosures relevant to the manuscript. Go to Neurology.org for full disclosures.

Correspondence to Dr. Ueno: yuji-u@juntendo.ac.jp 

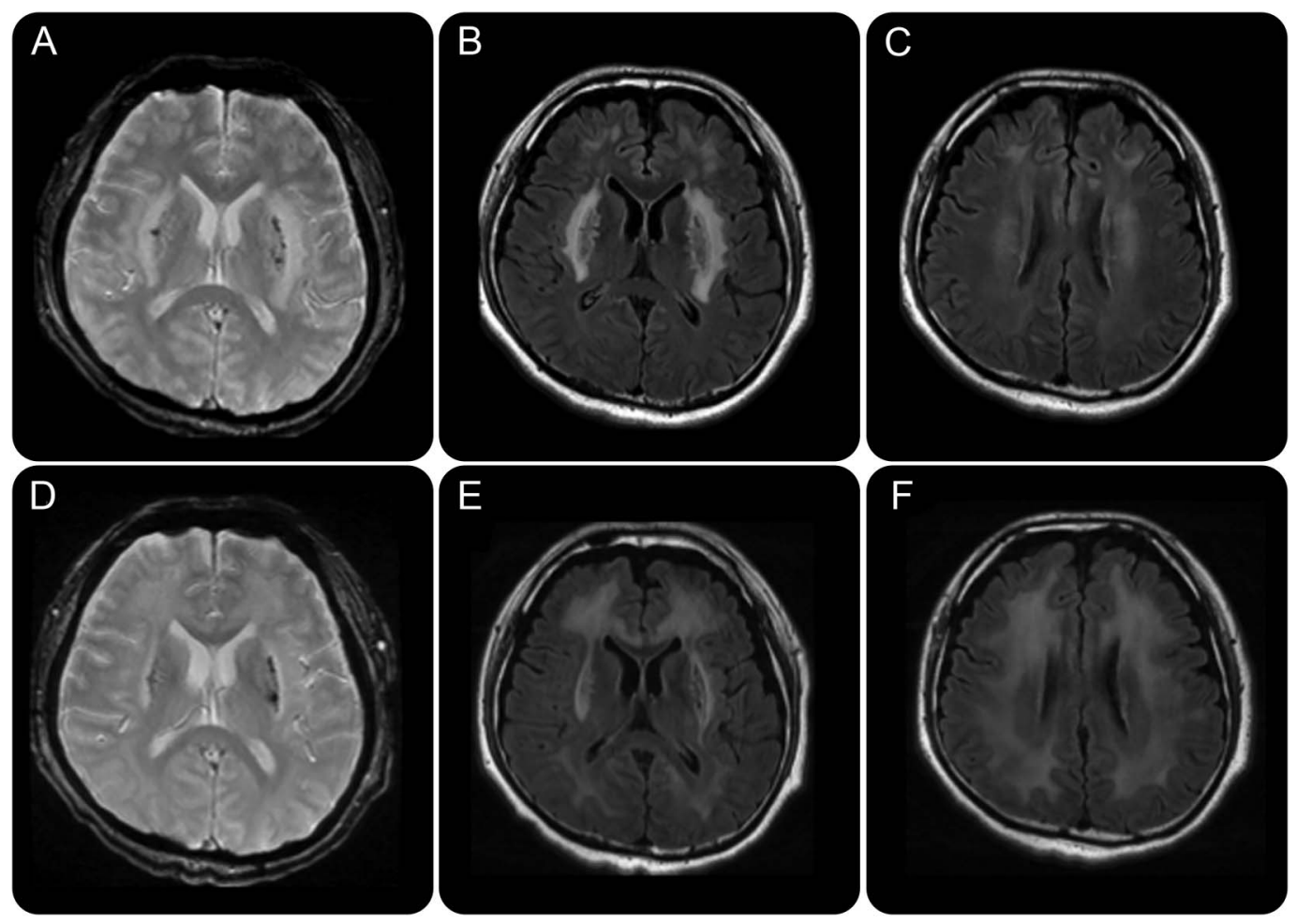

Representative images of repeat MRI on days $14(A-C)$ and $35(D-F)$ after admission; T2*-weighted images $(A, C)$ show scattered microbleeds in the bilateral putamen while fluid-attenuated inversion recovery images $(B, C, E, F)$ show putaminal lesions and chronic development of vast white matter lesions.

1. Skrzydlewska E. Toxicological and metabolic consequences of methanol poisoning. Toxicol Mech Methods 2003;13:277-293.

2. Ueno Y, Koike M, Shimada Y, et al. L-carnitine enhances axonal plasticity and improves white-matter lesions after chronic hypoperfusion in rat brain. J Cereb Blood Flow Metab 2015;35:382-391.

\section{WriteClick ${ }^{\circledR}$ rapid online correspondence}

The editors encourage comments about recent articles through WriteClick:

Go to Neurology.org and click on the "WriteClick" tab at the top of the page. Responses will be posted within 72 hours of submission.

Before using WriteClick, remember the following:

- WriteClick is restricted to comments about studies published in Neurology within the last eight weeks

- Read previously posted comments; redundant comments will not be posted

- Your submission must be 200 words or less and have a maximum of five references; reference one must be the article on which you are commenting

- You can include a maximum of five authors (including yourself) 


\section{Neurology}

\section{Acute hippocampal and chronic diffuse white matter involvement in severe methanol intoxication}

Haruka Takeshige, Yuji Ueno, Fuyuko Sasaki, et al.

Neurology 2016;87;2382-2383

DOI 10.1212/WNL.0000000000003382

This information is current as of November 28, 2016

\section{Updated Information \&} Services

References

Subspecialty Collections

Permissions \& Licensing

Reprints including high resolution figures, can be found at: http://n.neurology.org/content/87/22/2382.full

This article cites 2 articles, 0 of which you can access for free at: http://n.neurology.org/content/87/22/2382.full\#ref-list-1

This article, along with others on similar topics, appears in the following collection(s):

\section{Coma}

http://n.neurology.org/cgi/collection/coma

DWI

http://n.neurology.org/cgi/collection/dwi

MRI

http://n.neurology.org/cgi/collection/mri

Other toxicology

http://n.neurology.org/cgi/collection/other_toxicology

Information about reproducing this article in parts (figures,tables) or in its entirety can be found online at:

http://www.neurology.org/about/about_the_journal\#permissions

Information about ordering reprints can be found online:

http://n.neurology.org/subscribers/advertise

Neurology ${ }^{\circledR}$ is the official journal of the American Academy of Neurology. Published continuously since 1951, it is now a weekly with 48 issues per year. Copyright @ 2016 American Academy of Neurology. All rights reserved. Print ISSN: 0028-3878. Online ISSN: 1526-632X.

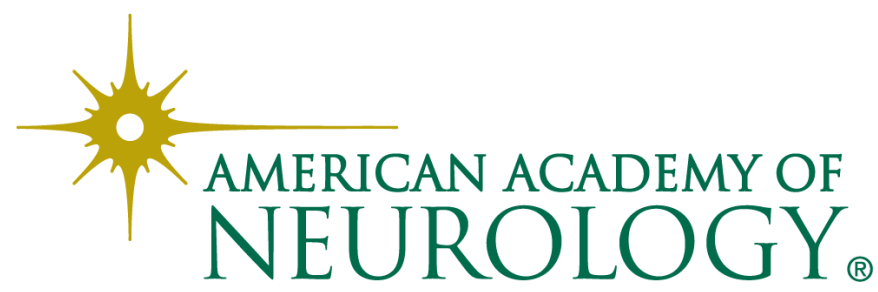

